\title{
Retrospective Study of Renal Failure in Dogs and Cats Admitted to University of Veterinary and Pharmaceutical Sciences Brno during 1999-2001
}

\author{
M. SOSNAR, P. KOHOUT, M. RU゚ŽIČKA, L. VRBASOVÁ
}

Small Animal Clinic, University of Veterinary and Pharmaceutical Sciences, Faculty of Veterinary Medicine, Brno, Czech Republic

Received March 6, 2002

Accepted March 25, 2003

\section{Abstract}

Sosnar M., P. Kohout, M. Růžička, L. Vrbasová: Retrospective Study of Renal Failure in Dogs and Cats Admitted to University of Veterinary and Pharmaceutical Sciences Brno during 1999-2001. Acta Vet. Brno 2003, 72: 593-598.

The purpose of the study was to determine the occurrence of acute renal failure (ARF), chronic renal failure $(\mathrm{CRF})$ and transitional forms, i.e. of ARF developing from chronic renal insufficiency (CRI), in dogs and cats in the Czech Republic. In addition, mortality and prognosis data were also processed within the framework of the study. The study contained only the patients admitted to the University clinic. Total number of admitted patients at the clinic during the period of the study was 1099 (935 dogs and 164 cats), the diagnosis of renal failure was determined in $139(12.7 \%)$ of these patients. The essential condition to include a patient in the study was the confirmation of intrarenal azotaemia. An analysis of monitored parameters was done in each patient in order to differentiate ARF from CRF. However, many owners of the animals with acute symptoms of RF decided for euthanasia after a consultation at the outpatient clinic and therefore the total prevalence of RF in the population of dogs and cats would be higher. Due to differences in the values of some monitored indices (prevalence of different types of RF; age of onset) it was necessary to evaluate dogs and cats separately. Total mortality due to RF was $76.6 \%$ in dogs and $57.1 \%$ in cats. In 45 patients $(32.4 \%)$ RF was caused by or connected with another disease. In 39 patients $(28.1 \%$; 38 dogs and one cat) only acute symptoms were detected. Chronic changes were demonstrated in 100 patients $(71.9 \% ; 73$ dogs and 27 cats). Most patients were presented rather late in the stage of decompensated CRI caused by various accompanying conditions (infection, renal ischaemia, diseases of other organs, etc.). The results of the work show that despite considerable achievements in small animal medicine in the Czech Republic during the recent years the success rate of treatment in patients with RF remains relatively low. Pursuit of preventive measures and complex screening in our patients (chiefly geriatric) represent the best way to manage RF. The study shows the correct approach to distinguish and treat renal failure in dogs and cats, and especially to establish the form of RF and subsequent prognosis. Azotaemia is only one of approximately 25 indices that should be assessed when examining a patient suffering from RF. It is essential for the correct diagnosis and prognosis.

Renal disorders, differend types, azotaemia, mortality, dialysis, small animals

There are numerous works on pathogenesis and manifestation of renal failure (RF) in veterinary medicine (Lulich at al. 1992; Lane at al. 1994; Senior 1994; Kučera 1999; Cowgill and Elliot 2000). However, the prevalence of different RF types is not exactly known. In general it is thought that ARF occurs less frequently than CRF (Kučera 1999). The objective of the present work was to determine the prevalence of different types of RF in the Czech Republic in the group of patients admitted at the University clinic. Due to the opportunity to apply extended set of diagnostic methods in these patients it was possible to distinguish different types of RF. Primary intrinsic (intrarenal) ARF is a result of direct nephrotoxic, ischaemic or infectious insult to kidneys. Secondary intrarenal ARF occurs

Address for correspondence:

MVDr. Martin Sosnar

Oblá 77

63400 Brno 
when prerenal or postrenal ARF is not adequately treated. CRF is a clinical syndrome occurring under the circumstances when the compensatory mechanisms in the kidneys suffering from long-term disease are unable to maintain their regular function and when this inability becomes irreversible (Kučera 1999). The condition of affected kidneys in many patients can be classified as ARF originated from chronic renal insufficiency (Lane at al. 1994). It is therefore not easy to determine the type of RF and thus also the prognosis. Usually it is inevitable to admit the patient to a clinic, apply detailed diagnostic procedures and determine the response to adequate therapy (development of azotaemia and general clinical condition). In older dogs the chronic condition becomes more frequent (Lulich at al. 1992; Brown 1999), and as it is irreversible the prognosis in older patients is poor (Senior 1994).

\section{Materials and Methods}

The study was carried out in the set of clinical records of 1099 patients (935 dogs and 164 cats) admitted at the Small Animal Clinic, University of Veterinary and Pharmaceutical Sciences Brno, during the period of 1999-2001. Out of this documentation the cases were selected which fulfilled the essential criteria of intrarenal azotaemia. The cases with prerenal or postrenal azotaemia, which were characteristic by the values of azotaemia returning to normal soon after complete rehydration and resumption of diuresis, were excluded from the study. Complete data necessary for the classification of the type of RF were not available in all patients. Therefore only such cases were selected in which it was possible to determine the type of RF. Emphasis was put on the conclusions from histological and/or ultrasonographic examination of kidneys. Clinical records with insufficient information were excluded from the study. Reference values for creatinine and urea were determined on the basis of examination of healthy adult dogs and cats. The physiological range for creatinine is $33-120 \mu \mathrm{mol} / 1$ in the dog and $50-180 \mu \mathrm{mol} / 1$ in the cat, for urea $2.5-8.2 \mathrm{mmol} / \mathrm{l}$ in the dog and 2.5-10.0 mmol/l in the cat. The patients were divided into categories according to the following parameters: age, duration and progression of the disease, recurrence of similar symptoms if any, severity of clinical symptoms with regard to the value of azotaemia, intake of fluids, production of urine, nutritional status, history of other diseases, physical examination focused on urogenital system (UGS), screening examination of urine and urine sample cultivation, haematological examination (haematocrit), biochemical examination (phosphorus, potassium) of blood, serological examination for leptospirosis, ultrasonographical examination of urinary system, development of the condition after the application of adequate therapy and production of urine after rehydration (Lulich at al. 1992; Lane at al. 1994; Senior 1994; Kučera 1999; Cowgill and Elliot 2000). Histological examination, which is optimal for the differentiation between acute and chronic changes and for the determination of prognosis (Lane at al. 1994), was carried out in 7 patients (5\%). In many patients admitted because of renal failure an intravital biopsy of kidneys would be too invasive with regard to their health status and was therefore contraindicated. The samples of kidney tissue from the patients with CRF collected post mortem or after recovery usually show the acute changes in a partially disguised form, nevertheless the conclusion on the basis of histological examination is always the most reliable one (Kučera 1999).

The aforementioned parameters were evaluated as follows: (1) a finding that suggests an acute condition (age up to five years, good nutritional status, sudden onset of symptoms, relatively low azotaemia with distinct clinical symptoms, oliguria to anuria, active urinary sediment, hyperkalaemia, acute changes confirmed by ultrasonographic kidney examination, progression or stabilisation of azotaemia after the start of treatment, positive histological finding; (2) atypical finding - possible for both ARF and CRF; (3) a finding that suggests a chronic process (age above 10 years, poor nutritional status, recurring kidney disease, relatively high values of azotaemia with mild symptoms, polyuria/polydipsia, inactive urinary sediment, hypokalaemia, anaemia, chronic changes confirmed by ultrasonographic kidney examination, reduction of azotaemia values and improved clinical condition after the start of treatment, histological finding). The parameters were scored with points and the patient was categorised into ARF, ARF developing from CRI, or CRF. Student's $t$-test and $\chi^{2}$-test were used for statistical analysis.

\section{Results and Discussion}

During the period from 1 January 1999 till 15 November 2001 there were 935 dogs and 164 cats (1 099 patients in total) admitted at the Department of Internal Medicine of the Clinic of Dogs and Cats, University of Veterinary and Pharmaceutical Sciences Brno. From this number 139 cases of intrarenal azotaemia were selected for detailed analysis.

The diagnosis of renal failure was determined in 111 dogs $(11.9 \%)$ and 28 cats $(17.1 \%)$. This made a total of 139 cases $(12.7 \%)$ out of all patients admitted at the University Clinic during the observed period. 
Dogs: 38 cases (34.2\%) were classified as ARF, equally 38 (34.2\%) as an acute condition developing in the kidneys with chronic insufficiency (i.e. ARF developing from CRI, a confirmed chronic process with acute manifestation), and 35 (31.6\%) as CRF. The differences between the prevalence values were not significant at of $p<0.05$.

Cats: one case (3.5\%) was classified as ARF, 18 cases (64.3\%) as CRF, and $9(32.2 \%)$ as ARF developing from CRI. CRF occurred in cats more frequently than other types of RF. Only a single ARF case was detected.

Mean age of the dogs with ARF was 9.2 years, while in CRF it was 8.7 years as well as in ARF developing from CRI. The age differences in dogs were not significant. Mean age of the cats with ARF was 14 years (in the single detected case). In CRF mean age of the affected cats was 10.4 years and in ARF developing from CRI it was 7.3 years. Mean age differences in cats were not significant either at $p<0.05$. The single case of ARF was not included in the analysis.

The aforementioned data are in agreement with literature. The incidence of ARF was not related to age, while the incidence of CRF increases with age (in particular in cats older than ten years) (Brown 1999).

Acute changes only were detected in $38 \mathrm{dogs}(34.2 \%)$ and in one cat (3.6\%), i.e. in a total of 39 patients (28.1\%). Chronic changes were detected in 73 dogs $(65.8 \%)$ and 27 cats $(96.4 \%)$, i.e. in a total of 100 patients $(71.9 \%)$.

There were 94 cases (67.6\%) with unknown aetiology (idiopathic). In 45 patients (32.4\%) with RF a causative relation or connection with another disease was confirmed. The concurrent conditions included heart disease leading to heart failure in 15 cases $(10.8 \%)$, neoplasia in 9 cases $(6.5 \%)$, pyometra in 5 cases (3.6\%), diabetes mellitus in 4 cases $(2.9 \%)$, hepatic disease in 3 cases (2.2\%), leptospirosis likewise in three cases $(2.2 \%)$, pancreatitis in two cases (1.4\%), plus the following conditions which were always found in a single patient $(0.7 \%)$ only: testicular torsion, autoimmune haemolytic anaemia, prostatitis, and intoxication by non-steroidal anti-inflammatory drugs.

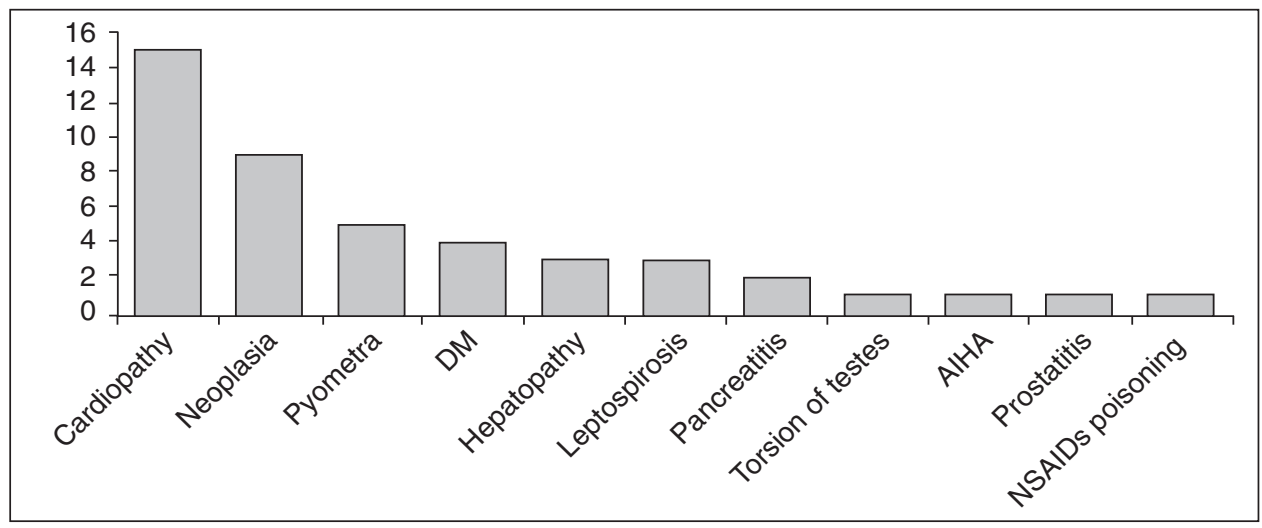

Fig. 1. The most common causes or complications of RF in our study

Mortality values in the dogs were found as follows: $76.3 \%$ in the dogs with ARF, $83.8 \%$ with ARF developing from CRI, and $63.9 \%$ with CRF. Total mortality in the dogs with RF was $76.6 \%$. There were no significant differences in mortality values in the dogs. Mortality values in the cats with ARF was $100.0 \%$ (however only in a single case detected), with ARF developing from CRI $25.0 \%$ and with CRF $68.4 \%$. Total mortality in the cats with CRF was significantly higher than in the cats with ARF developing from CRI. The single case of ARF was not included in the evaluation. 
Table 1

Occurrence of different types of RF in dogs and cats

\begin{tabular}{|c|c|c|c|}
\hline & Dogs & Cats & Total \\
\hline ARF & 38 & 1 & 39 \\
\hline ARF/CRI & 38 & 9 & 47 \\
\hline CRF & 35 & 18 & 53 \\
\hline RF & 111 & 28 & 139 \\
\hline Age with ARF years & $9.2(1-15)$ & $14(14)$ & \\
\hline Age with ARF/CRI years & $8.7(1-15)$ & $7.3(1-13)$ & \\
\hline Age with CRF years & $8.7(1-16)$ & $10.4(2-18)$ & \\
\hline Acute changes & $34.2 \%$ & $3.5 \%$ & $28.1 \%$ \\
\hline Chronic changes & $65.8 \%$ & $96.4 \%$ & $71.1 \%$ \\
\hline ARF mortality & $76.3 \%$ & $100.0 \%$ & \\
\hline ARF/CRI mortality & $83.8 \%$ & $25.0 \%$ & \\
\hline CRF mortality & $63.9 \%$ & $68.4 \%$ & \\
\hline
\end{tabular}

The patients with RF were presented relatively very frequently. RF belongs among the three most frequent causes of death in the dogs and cats of an advanced age. In veterinary medicine azotaemia is usually the first sign to indicate RF (B rown 1999; Kučera 1999), because the more sensitive methods for the detection of earlier stages of RF (CT, magnetic resonance, scintigraphy) (Osborne 1995; Armbrust at al. 2001) are not available. Azotaemia usually occurs only after renal decompensation, which is a sign of a damage to more than 75\% of functional renal parenchyma (Lulich at al. 1992; Lane at al. 1994; Senior 1994; Brown 1999; Kučera 1999; Cowgill and Elliot 2000). In case of intrarenal aetiology of azotaemia the prognosis remains at least uncertain. On the other hand, ARF is a potentially reversible condition, and therefore an attempt to treat these patients is fully justified. If an animal survives the acute onset of the disease, the long-term prognosis is good when adequate care is given to the patient (Lulich at al. 1992; Lane at al. 1994; Senior 1994; Kučera 1999). On the contrary, if the onset of clinical symptoms caused by $\mathrm{CRI}$ is slow, the condition usually develops in a failure of renal compensatory mechanisms and due to irreversible nature of the changes the prognosis is poor in short term. (Lulich at al. 1992; Senior 1994). However, even in such cases, if sufficient quantity of functional renal parenchyma is maintained and if CRI is appropriately managed, there is a chance that the condition could be stabilised and CRF progression retarded (Brown 1999). CRI prevalence significantly increases with age and the condition will become a predisposition factor for ARF or directly develops into CRF (Lulich at al. 1992; B rown 1999). Many of the cases are classified as ARF developing in CRI (Lane at al. 1994). This means that a chronic primary renal disease (frequently not detectable by available methods) was exacerbated by any of the possible causes of ARF (hypovolaemia, nephrotoxicosis, infection) (B rown 1999). In such cases the clinical diagnosis has to consider both the acute manifestation and the chronic irreversible changes of the kidneys affected by CRI. Owing to the immense compensatory capacity of kidneys the processes that lead to the affection of less than $75 \%$ of kidney parenchyma are not manifested by azotaemia (Lulich at al. 1992; Lane at al. 1994; Senior 1994; Brown 1999; Kučera 1999; Cowgill and Elliot 2000). On the other hand, it is possible to be presented with patients dying from RF without any apparent intravital changes in the morphology of the kidneys. Post mortem examination of kidney tissue samples will show acute changes which, however, cannot be detected by ultrasound. Diffuse changes are most frequently detected by ultrasound. In case of ARF the kidneys were usually of a normal size or enlarged (normal or reduced size in CRF), the edges were smooth and the cortex was diffusely hypoechogenic (hyperechogenic in CRF). Renal 
ultrasonography cannot be therefore considered a good screening method (O s borne 1995). It can be concluded from the number of histological examinations carried out that this method is not a standard for practical diagnosis in the patients with RF under local conditions. The most frequent findings included acute and chronic glomerulonephritis, chronic pyelonephritis, fibrosis, hydronephrosis, renal dysplasia. Neoplasia findings consisted of infiltrating adenopapillary-transitional carcinoma, metastasizing clarocellular carcinoma and malignant histiocytosis. The findings were similar to the data in literature (Kučera 1999). Not all of the monitored parameters were of the same importance for the classification of RF. The evaluation of the criteria observed in the present work allowed a safe detection of both extremes, i.e. typical ARF or CRF. In ARF developing of CRI it was possible to assess the rate of chronic changes and to identify the patients with poor prognosis. Even after the classification based on aforementioned examinations there will be a remaining group of patients wherein no prognosis can be determined without a knowledge of a response to adequate therapy (Lane at al. 1994). Development of the clinical condition in the patient and the production of urine after the application of infusion therapy belong among the most important data.

In a patient with predominant $\mathrm{CRF}$ a resolute administration of fluid therapy will lead to renal hyperperfusion, increased urine production and subsequent stabilisation (Lane at al. 1994). In most cases this is also accompanied by a reduction in the levels of creatinine, urea and phosphorus. The animal will stop vomiting, start to eat and its clinical condition will substantially improve. However, a long-term prognosis is paradoxically poor because it is justified to suppose problems due to chronic changes (Lane at al. 1994).

In a patient with predominant acute changes it is possible to watch an opposite development (Lane at al. 1994). If the production of urine is sufficient after the start of the fluid therapy, the levels of creatinine, urea and phosphorus may stabilise after the initial increase and azotaemia may possibly get to normal during the subsequent weeks (Lane at al. 1994). If the production of urine is insufficient (oliguria to anuria - suspect for ARF), azotaemia will continue to develop and the patient may even die when the resumption of full-scale diuresis fails within several hours. Death will be usually caused by the sequelae of the uremic syndrome (pneumonia, gastroenteritis, acidosis), frequently also by heart failure or excessive hydration (Lane at al. 1994; Kučera 1999).

The surviving patients usually suffered from another primary disease which was caused or related to RF. For instance 15 patients (10.8\%) suffered from heart disease, 5 patients (3.6\%) from pyometra, etc. In these cases RF was a secondary complication. If the underlying problem is cured or stabilised the same may be also true for RF and the prognosis will get better (Lane at al. 1994).

Lower mortality in cats $(57.1 \%)$ compared to dogs $(76.6 \%)$ was due to the fact that many feline patients will react to the fluid therapy by significant clinical improvement and will be discharged after several days after admission at the clinic. However, under the conditions of normal load to the organism the renal function will again become insufficient after several days and the symptoms of uremia will reappear. In such patients subsequent euthanasia is often the final solution, although it was not possible to confirm this in most of the older cases, as the data were missing in the clinical records. Therefore the mortality of the dogs with RF seems to be higher.

\section{Výskyt typů selhávání ledvin u psů a koček hospitalizovaných na VFU Brno v letech 1999-2001 - retrospektivní studie}

Účelem studie bylo určit frekvenci výskytu akutního (ARF), chronického (CRF) a přechodných forem selhání ledvin (ARF na CRI - chronické renální insuficienci) u psů a koček v podmínkách České republiky, a souvislosti s mortalitou a prognózou. Do studie 
byli zařazeni pouze hospitalizovaní pacienti, kterých bylo za sledované období 1099 (935 psů a 164 koček), diagnóza renální selhání byla stanovena u 139 (12,7 \%). Základní podmínkou pro zařazení pacienta do studie byla azotemie intrarenálního původu. U každého případu byly vyhledány parametry, které umožňují rozlišit ARF od CRF. Řada majitelů pacienta s akutní manifestací RF se však po ambulantní konzultaci rozhodne pro eutanázii, takže celková prevalence RF v populaci psů a koček je vyšší. Vzhledem k rozdílům v hodnotách některých sledovaných údajů mezi psy a kočkami (výskyt jednotlivých typů RF; věk při rozpoznání RF) byli tito hodnoceni zvlášt. Celková mortalita psů s RF byla 76,6 $\%$, mortalita koček s RF byla 57,1 \%. U $45(32,4 \%)$ pacientů byla zjištěna příčina RF nebo souvislost s jiným onemocněním. U $39(28,1 \%)$ pacientů byly zjištěny pouze akutní změny, chronické změny byly prokázány u $100(71,9 \%)$ pacientů. Většina pacientů byla tedy předvedena až ve stadiu dekompenzace CRI z různých důvodů (infekce, ischemie ledvin, onemocnění jiných orgánů, apod.), což zhoršuje prognózu a zvyšuje mortalitu. Důvodem pozdní diagnostiky je ve veterinární medicíně na jedné straně absence diagnostických metod pro časnější detekci postižení ledvin (MRI, scintigrafie), a na straně druhé asymptomatický vývoj nemoci. Př́iliš málo zviŕrat pravidelně podstupuje preventivní vyšetření (zejména screening geriatrického pacienta), což je hlavní důvod, proč bývá diagnóza stanovena tak pozdě. Mnoho majitelů $\mathrm{v}$ době zjištění závažné azotemie již nesouhlasí s rozsáhlejším screeningem pacienta. $K$ vyšší mortalitě přispívá i nedostupnost finančně a technicky náročných terapeutických možností (dialýza, transplantace ledvin), běžně používaných v humánní medicíně, a dále rozdíly mezi člověkem a zvířaty (velikost těla, spolupráce při dialýze atd.). Práce ukazuje správný přístup při diferenciaci a léčbě renálního selhání u psů a koček, zejména při určování formy a následné prognózy renálního selhání. Azotémie je pouze jedním z přibližně 25 parametrů, které by měly být při vyšetřování pacienta postiženého selháním ledvin a stanovování diagnózy a prognózy zhodnoceny.

\section{Acknowledgement}

The study was supported by the grant of the Czech Ministry of Education, Youth and Sports No. $161700002 / 2001$.

\section{References}

ARMBRUST, LJ, BILLER, DS, HOSKINSON, JJ, MEIER, HT, MICHIELS, ML 2001: The basics of renal ultrasonography. Vet Med 114-133

BROWN, SA 1999: Evaluation of chronic renal disease: a staged approach. Comp Cont Ed 21:752-763

COWGILL, LD, ELLIOT, DA 2000: Acute renal failure. In: ETTINGER, SJ, FELDMANN, EC (Ed.): Textbook of veterinary internal medicine. WB Saunders Company, Philadelphia, pp. 1615-1633

KUČERA, J 1999: Nefrologie a urologie psa a kočky. Noviko, Brno, 194 p.

LANE, IF, GRAUER, GF, FETTMAN, MJ 1994: Acute renal failure. Part I. Risk factors, Prevention, strategies for Protection. In: ROSS, LA (Ed.): Compendium Collection. Veterinary Learning Systems, New Jersey, pp. 8-19

LANE, IF, GRAUER, GF, FETTMAN, MJ 1994: Acute renal failure. Part II. Diagnosis, Management and Prognosis. In: ROSS, LA (Ed.): Compendium Collection. Veterinary Learning Systems, New Jersey, pp. 20-30

LULICH, JP, OSBORNE, CA, O'BRIEN, TD, POLZIN, DJ 1992: Feline renal failure: Questions, answers, questions. Comp Cont Ed 14:127-151

OSBORNE, CA, FINCO, DR 1995: Diseases of the Kidney. In: OSBORNE, CA, FINCO, DR (Ed).: Canine and Feline Nephrology and Urology. Williams \& Wilkins, Philadelphia, pp. 335-602

SENIOR, DF 1994: Management of chronic renal failure in the dog. In: ROSS, LA (Ed.): Compendium Collection. Veterinary Learning Systems, New Jersey, pp. 31-41 